University of Nebraska - Lincoln

DigitalCommons@University of Nebraska - Lincoln

Sociology Department, Faculty Publications

Sociology, Department of

April 1986

\title{
The Multidimensionality of Joining
}

Suzanne T. Ortega

University of Nebraska-Lincoln, ortegas@u.washington.edu

J. Allen Williams Jr.

University of Nebraska-Lincoln, jwilliams2@unl.edu

Follow this and additional works at: https://digitalcommons.unl.edu/sociologyfacpub

Part of the Sociology Commons

Ortega, Suzanne T. and Williams, J. Allen Jr., "The Multidimensionality of Joining" (1986). Sociology Department, Faculty Publications. 3.

https://digitalcommons.unl.edu/sociologyfacpub/3

This Article is brought to you for free and open access by the Sociology, Department of at DigitalCommons@University of Nebraska - Lincoln. It has been accepted for inclusion in Sociology Department, Faculty Publications by an authorized administrator of DigitalCommons@University of Nebraska - Lincoln. 


\title{
The Multidimensionality of Joining
}

\author{
J. Allen Williams, Jr., and Suzanne T. Ortega \\ Department of Sociology, University of Nebraska-Lincoln, Lincoln, NE 68588
}

\begin{abstract}
By focusing on membership in voluntary associations in general, the question of whether correlates of affiliation vary by organizational type tends to have been neglected. This is a significant omission from the standpoint of describing the characteristics of "joiners." Additionally, most of what we know about the reasons for belonging has been inferred from observations of who joins. In this study, nine frequently identified correlates of voluntary association membership were examined in relation to five different types of organizations. Only two, education and race, were found to be related to all types. Thus, results indicate that affiliation is not a unidimensional process and memberships in different types of associations are not interchangeable.
\end{abstract}

The extensive literature on participation in voluntary associations provides considerable information about the characteristics of people who belong. This literature, in turn, has been used to develop rather elaborate theories regarding individual reasons for joining. An assumption underlying much of the empirical and theoretical work is that affiliation is unidimensional, i.e., that those social and demographic factors associated with belonging to one type of organization are equally relevant for other types. Indeed, one central proposition in the literature relates to the "cumulative effect" of social participation, suggesting that belonging to one organization increases the likelihood of belonging to another (cf. Smith and Freedman, 1972; Tomeh, 1973). Additionally, research has examined whether voluntary association membership is positively correlated with other forms of social participation, such as visiting friends and exposure to mass media (cf. Allardt et al., 1958; Babchuk and Thompson, 1962; Jacoby, 1966).

A recent study by Edwards and White (1980) has extended this line of questioning by investigating whether selected demographic predictors of membership in voluntary associations also predict other types of social activity. Our search of the literature, however, has uncovered no studies which address this important issue with respect to membership in different types of voluntary associations. In other words, do the generally established social and demographic predictors of membership have equal relevance for all types of voluntary associations? Are they unidimensional or multidimensional? The answer to this question is especially important with respect to theories both about the characteristics of people who join voluntary associations and why they belong (cf. Smith, 1975).

Three major methodological approaches have been used to study the correlates of voluntary group membership. The most frequently used strategy considers either who belongs 
to an organization (cf. Curtis, 1971; Hyman and Wright, 1971) or the number of organizations belonged to (cf. Knoke and Thomsen, 1977; Klobus-Edwards et al., 1978; Edwards and White, 1980), without reference to the kind of association it is. In this regard, McPherson (1981:708) comments that, "There are literally dozens of articles in the voluntary association literature which simply count the number of memberships, treating each as interchangeable with the other." Consequently, it is unclear from this approach whether affiliation is a general propensity or if different factors lead to joining depending upon the particular nature of the organization.

In contrast to the studies combining memberships, a few have dealt with belonging to a single organization or specific type of association (cf. Sills, 1957; Schmidt, 1980). It is clear, however, that knowing the characteristics of members in one group or type of group does not allow for a determination of whether these characteristics are those of joiners, regardless of the kind of organization, or of those choosing to affiliate with that specific kind of association.

A third category includes those studies that have examined belonging to various types of groups, but that have focused only on specific substantive issues about who joins, such as whether blacks participate more than whites (cf. Williams and St. Peter, 1977; Guterbock and London, 1983), the elderly participate more than others (cf. Cutler, 1977; Babchuk et al., 1979), or if middle-class persons participate more than those in the working or lower class (cf. Booth et al., 1968). These studies have either relied on tabular analysis of one or two independent variables or have focused on the independent effects of a single variable without presenting the data necessary to assess how the control variables are related to affiliation (cf. Babchuk and Booth, 1969). For instance, Jacoby (1966) found that living arrangements had different effects depending on whether membership was in expressive or instrumental organizations. Babchuk and Booth (1969) found age, sex, and age by sex differences in types of organizational memberships. Similarly, Edwards et al. (1984) found sex differences in types of organizational affiliations, even after controlling for such variables as occupational prestige, marital status, and income. None of these studies, however, allows one to determine whether these variables, e.g., age, sex, race, have independent, differential effects by type or organization. Thus, these and similar studies provide useful information about whether specific factors are associated with joining more than one organization, but they do not answer the more general question of whether there are a set of characteristics associated with joining.

Those few studies that more directly examine the unidimensionality/multidimensionality of formal voluntary association membership appear to challenge the widespread assumption of unidimensionality. Using factor analytic techniques, Houghland (1979) found that two dimensions underlie membership in different types of organizations. Houghland and Christenson (1982) provide evidence that values differentially affect belonging to various types of organizations, independent of covariates such as income, age, education, and community size. Thus, while limited to a North Carolina sample, their data clearly suggest a multidimensional process. Some theoretical work pertaining to membership also suggests the multidimensionality of joining. For example, from Lemon et al. (1972) it can be predicted that status characteristics will be differentially related to membership in that the emphasis is placed on the differing goals and membership requirements of groups rather than the characteristics of joiners. 
In contrast to the many studies that have used community or regional samples, we use a representative national sample of 3,075 adult Americans to examine the independent and interactive effects of nine social and demographic variables, often reported to be important determinants of affiliation, on five of the most common forms of voluntary associations.

\section{Sample and Research Design}

The data for this study were collected by Response Analysis of Princeton, New Jersey in 1973. It is a probability sample of persons age eighteen and older residing in the contiguous United States. From the occupied and eligible households drawn for the sample, 3,540 successful interviews were completed yielding a response rate of 70 percent. The refusal rate is 17 percent with the other non-completions stemming primarily from designated respondents not being home after four visits. The samples of minority racial groups other than blacks were deemed too small for proper analysis. Thus, these cases, along with those for whom complete information is not available, were deleted, leaving 3,075 cases fur the present study. For further details about the sample, see Nunn et al. (1978).

Voluntary association memberships were measured by showing respondents a card listing five different types of organizations. The types are church-related, job-related, recreational, fraternal/service, and civic/political. (An “other” category was included also, but is not used in the present study since the focus is on membership in specific types of associations.) The respondent was asked, "Which of these types of organizations, if any, do you belong to?" Recall was aided by providing the respondent with examples of different types of associations. For example, Lions, Masons, Eastern Star, and Rotary were mentioned in relation to fraternal/service organizations.

The nine independent variables selected for analysis are: education, race, gender, age, marital status, whether the respondent is a household head, number of children under 18 years of age residing at home, size of the respondent's community and region of residence. These variables are the ones figuring most prominently in the sociological literature dealing with participation in voluntary associations and thus the ones which should receive primary attention. Region provides a useful control in that many of the previous studies are based on samples drawn from a single area of the nation, leaving the generalizability of their findings unknown.

The method of data analysis is the linear probability estimation technique developed by Grizzle et al. (1969). This procedure allows one to estimate the effects of independent variables on a dichotomous dependent variable, while simultaneously controlling for the effects of all other variables in the analysis. The model is similar to regression analysis and the interpretation of the resulting coefficients is nearly identical. One major difference, however, is the substitution of an appropriate Chi-Square test of significance for what would be a questionable use of an F-test (Swafford, 1980).

\section{Findings}

Table 1 shows the levels of statistical significance for the relationships of organizational types with each of the independent variables, controlling for each of the other variables. It 
can be seen that two of the independent variables, education and race, are significantly associated with all five types of voluntary associations. As might be expected, education is quite strongly associated with belonging to job-related associations. Although the magnitude is less for the others, the association is considerable for all forms. Race also has relatively large and consistent effects on memberships. The association with church-related organizations is strongest, but all are significant. Thus, for these variables the assumption that memberships in different organizations are interchangeable appears warranted. However, examination of all of the other independent variables shows considerable variation in effects on different types of memberships. In other words, then, seven of the nine variables appear to be multidimensional with respect to joining - they are organizationally-specific determinants.

Table 1 also shows coefficients based on the linear probability model for the nine independent variables by type of organization. These data provide an indication of the nature of the association between the independent variables and each of the specific types of voluntary associations. It can be seen that for all organizational types, the higher the level of education, the greater the likelihood of belonging. The range is greatest for job-related groups with those having less than eight years of education twelve percent below those with an education beyond high school, but education makes a good deal of difference for all types.

Holding other factors constant, the proportion of blacks belonging to civic/political, jobrelated and recreational organizations exceeds the white rate by about six percent. The difference is eight percent for fraternal/service groups and twelve percent for church-related associations.

Males are more likely than females to belong to job-related and fraternal/service associations; the difference is about eight percent in both cases. However, women are not less likely to belong to recreational and civic/political groups and are more likely than men to belong to church-related associations. The effects of gender on belonging differ, then, not only in strength but in direction as well, depending upon the type of organization under consideration.

Age is strongly associated with the probability of belonging to church-related, fraternal/ service, and civic/political organizations. It can be seen from the table that these associations are similar to each other with a general rise in the likelihood of belonging with increasing age until about age 75. At that point participation reaches a plateau for church-related and civic/ political groups and declines slightly for fraternal/service organizations. However, age is not related to membership in recreational and job-related groups.

From the standpoint of current sociological thinking, one of the most interesting findings is the direct, negative effect of marital status on voluntary association membership. A review of the literature indicates that the common assumption that married persons are more likely to participate in associations actually rests on weak empirical evidence. Curtis (1971), for instance, finds only a small bivariate relationship. O'Donnell (1983) has indicated that parenthood is a salient variable with respect to participation and Knoke and Thomsen (1977) have suggested that the interaction of age, marital status, and the presence of children as they combine to produce stages in the "family life cycle" is more important to voluntary association membership than any of those variables alone. In any case, data from the present study indicate that being married, independent of the presence of children in the household, depresses 
Table I

Coefficients Based on the Linear Probability Model for Nine Variables by Organizational Type

\begin{tabular}{|c|c|c|c|c|c|}
\hline & $\begin{array}{l}\text { Church- } \\
\text { related }\end{array}$ & $\begin{array}{l}\text { Job- } \\
\text { related }\end{array}$ & Recreational & $\begin{array}{c}\text { Fraternal/ } \\
\text { Service }\end{array}$ & $\begin{array}{c}\text { Civicl } \\
\text { Political }\end{array}$ \\
\hline Constant & $\begin{array}{l}.440 \\
(.013)^{\mathrm{a}}\end{array}$ & $\begin{array}{l}.363 \\
(.013)\end{array}$ & $\begin{array}{l}.375 \\
(.013)\end{array}$ & $\begin{array}{l}.381 \\
(.013)\end{array}$ & $\begin{array}{l}.372 \\
(.013)\end{array}$ \\
\hline Education & $* * * \mathbf{b}$ & $* * *$ & $* * *$ & $* * *$ & $* * *$ \\
\hline $0-8$ & $\begin{array}{c}-.045 \\
(.012)\end{array}$ & $\begin{array}{c}-.040 \\
(.012)\end{array}$ & $\begin{array}{l}-.037 \\
(.012)\end{array}$ & $\begin{array}{l}-.034 \\
(.012)\end{array}$ & $\begin{array}{l}-.041 \\
(.012)\end{array}$ \\
\hline $9-11$ & $\begin{array}{c}-.013 \\
(.011)\end{array}$ & $\begin{array}{r}-.019 \\
(.011)\end{array}$ & $\begin{array}{c}-.022 \\
(.011)\end{array}$ & $\begin{array}{l}.001 \\
(.011)\end{array}$ & $\begin{array}{l}.000 \\
(.010)\end{array}$ \\
\hline 12 & $\begin{array}{l}.022 \\
(.010)\end{array}$ & $\begin{array}{l}-.021 \\
(.010)\end{array}$ & $\begin{array}{l}.005 \\
(.010)\end{array}$ & $\begin{array}{l}-.007 \\
(.009)\end{array}$ & $\begin{array}{c}-.009 \\
(.009)\end{array}$ \\
\hline $13+$ & $\begin{array}{l}.036 \\
(.010)\end{array}$ & $\begin{array}{l}.080 \\
(.010)\end{array}$ & $\begin{array}{l}.054 \\
(.010)\end{array}$ & $\begin{array}{l}.040 \\
(.010)\end{array}$ & $\begin{array}{l}.050 \\
(.010)\end{array}$ \\
\hline Race & $* * *$ & $* *$ & $* * *$ & $* * *$ & $* * *$ \\
\hline White & $\begin{array}{l}-.057 \\
(.009)\end{array}$ & $\begin{array}{l}-.027 \\
(.009)\end{array}$ & $\begin{array}{c}-.032 \\
(.009)\end{array}$ & $\begin{array}{c}-.038 \\
(.009)\end{array}$ & $\begin{array}{c}-.033 \\
(.009)\end{array}$ \\
\hline Black & $\begin{array}{c}.057 \\
(.009)\end{array}$ & $\begin{array}{c}.027 \\
(.009)\end{array}$ & $\begin{array}{c}.032 \\
(.009)\end{array}$ & $\begin{array}{c}.038 \\
(.009)\end{array}$ & $\begin{array}{c}.033 \\
(.009)\end{array}$ \\
\hline Gender & $* * *$ & $* * *$ & & $* * *$ & \\
\hline Male & $\begin{array}{l}-.027 \\
(.008)\end{array}$ & $\begin{array}{c}.035 \\
(.008)\end{array}$ & $\begin{array}{l}.009 \\
(.008)\end{array}$ & $\begin{array}{c}.032 \\
(.008)\end{array}$ & $\begin{array}{c}.002 \\
(.008)\end{array}$ \\
\hline Female & $\begin{array}{c}.027 \\
(.008)\end{array}$ & $\begin{array}{c}-.035 \\
(.008)\end{array}$ & $\begin{array}{c}-.009 \\
(.008)\end{array}$ & $\begin{array}{c}-.032 \\
(.008)\end{array}$ & $\begin{array}{c}-.002 \\
(.008)\end{array}$ \\
\hline Age & $* * *$ & & & $* * *$ & $* * *$ \\
\hline $18-29$ & $\begin{array}{l}-.106 \\
(.014)\end{array}$ & $\begin{array}{c}-.001 \\
(.014)\end{array}$ & $\begin{array}{l}-.005 \\
(.014)\end{array}$ & $\begin{array}{l}-.062 \\
(.013)\end{array}$ & $\begin{array}{l}-.062 \\
(.013)\end{array}$ \\
\hline $30-54$ & $\begin{array}{l}-.031 \\
(.012)\end{array}$ & $\begin{array}{c}.007 \\
(.012)\end{array}$ & $\begin{array}{c}-.013 \\
(.012)\end{array}$ & $\begin{array}{l}-.036 \\
(.011)\end{array}$ & $\begin{array}{l}-.015 \\
(.012)\end{array}$ \\
\hline $55-64$ & $\begin{array}{c}.043 \\
(.014)\end{array}$ & $\begin{array}{c}.027 \\
(.014)\end{array}$ & $\begin{array}{l}.002 \\
(.013)\end{array}$ & $\begin{array}{l}.020 \\
(.014)\end{array}$ & $\begin{array}{l}.022 \\
(.013)\end{array}$ \\
\hline $65-74$ & $\begin{array}{l}.054 \\
(.017)\end{array}$ & $\begin{array}{r}-.010 \\
(.016)\end{array}$ & $\begin{array}{l}.007 \\
(.016)\end{array}$ & $\begin{array}{c}.047 \\
(.016)\end{array}$ & $\begin{array}{l}.025 \\
(.016)\end{array}$ \\
\hline $75+$ & $\begin{array}{l}.040 \\
(.021)\end{array}$ & $\begin{array}{c}-.023 \\
(.020)\end{array}$ & $\begin{array}{l}.009 \\
(.020)\end{array}$ & $\begin{array}{l}.030 \\
(.020)\end{array}$ & $\begin{array}{l}.030 \\
(.020)\end{array}$ \\
\hline
\end{tabular}

participation in all types of associations except those related to church. On the other hand, the presence of children in the household is independently associated with participation in fraternal/service and civic/political groups. 
Table I (continued)

\begin{tabular}{|c|c|c|c|c|c|}
\hline & $\begin{array}{l}\text { Church- } \\
\text { related }\end{array}$ & $\begin{array}{l}\text { Job- } \\
\text { related }\end{array}$ & Recreational & $\begin{array}{c}\text { Fraternal/ } \\
\text { Service }\end{array}$ & $\begin{array}{c}\text { Civicl } \\
\text { Political }\end{array}$ \\
\hline Marital Status & & $*$ & $* *$ & $* * *$ & $* * *$ \\
\hline Single & $\begin{array}{c}.008 \\
(.015)\end{array}$ & $\begin{array}{c}.014 \\
(.015)\end{array}$ & $\begin{array}{l}-.005 \\
(.015)\end{array}$ & $\begin{array}{c}.005 \\
(.015)\end{array}$ & $\begin{array}{c}.009 \\
(.015)\end{array}$ \\
\hline Married & $\begin{array}{l}-.004 \\
(.011)\end{array}$ & $\begin{array}{c}-.026 \\
(.011)\end{array}$ & $\begin{array}{c}-.040 \\
(.011)\end{array}$ & $\begin{array}{l}-.047 \\
(.010)\end{array}$ & $\begin{array}{r}-.043 \\
(.010)\end{array}$ \\
\hline $\begin{array}{l}\text { Separated/ } \\
\text { Divorced }\end{array}$ & $\begin{array}{r}-.015 \\
(.017)\end{array}$ & $\begin{array}{c}.028 \\
(.017)\end{array}$ & $\begin{array}{c}.027 \\
(.017)\end{array}$ & $\begin{array}{c}.045 \\
(.017)\end{array}$ & $\begin{array}{l}.031 \\
(.017)\end{array}$ \\
\hline Widowed & $\begin{array}{l}.011 \\
(.017)\end{array}$ & $\begin{array}{c}-.016 \\
(.016)\end{array}$ & $\begin{array}{l}.018 \\
(.016)\end{array}$ & $\begin{array}{c}-.003 \\
(.017)\end{array}$ & $\begin{array}{l}.003 \\
(.016)\end{array}$ \\
\hline Household head & & $* *$ & & & \\
\hline Head & $\begin{array}{l}-.003 \\
(.009)\end{array}$ & $\begin{array}{l}.024 \\
(.009)\end{array}$ & $\begin{array}{c}-.011 \\
(.009)\end{array}$ & $\begin{array}{l}.008 \\
(.009)\end{array}$ & $\begin{array}{c}-.011 \\
(.009)\end{array}$ \\
\hline Not Head & $\begin{array}{l}.003 \\
(.009)\end{array}$ & $\begin{array}{l}-.024 \\
(.010)\end{array}$ & $\begin{array}{c}.011 \\
(.009)\end{array}$ & $\begin{array}{c}-.008 \\
(.009)\end{array}$ & $\begin{array}{c}.011 \\
(.009)\end{array}$ \\
\hline \multicolumn{4}{|c|}{ Number of Children } & $*$ & $* * *$ \\
\hline 0 & $\begin{array}{l}-.014 \\
(.009)\end{array}$ & $\begin{array}{c}.000 \\
(.009)\end{array}$ & $\begin{array}{c}-.014 \\
(.009)\end{array}$ & $\begin{array}{l}-.012 \\
(.009)\end{array}$ & $\begin{array}{c}-.056 \\
(.009)\end{array}$ \\
\hline I & $\begin{array}{c}.015 \\
(.010)\end{array}$ & $\begin{array}{l}.-18 \\
(.010)\end{array}$ & $\begin{array}{c}.013 \\
(.010)\end{array}$ & $\begin{array}{c}.025 \\
(.010)\end{array}$ & $\begin{array}{c}.022 \\
(.010)\end{array}$ \\
\hline $2+$ & $\begin{array}{c}-.001 \\
(.009)\end{array}$ & $\begin{array}{r}-.018 \\
(.010)\end{array}$ & $\begin{array}{l}.001 \\
(.009)\end{array}$ & $\begin{array}{c}-.013 \\
(.009)\end{array}$ & $\begin{array}{l}.034 \\
(.009)\end{array}$ \\
\hline Community size & $*$ & & $*$ & & $* *$ \\
\hline $100,000+$ & $\begin{array}{c}-.010 \\
(.009)\end{array}$ & $\begin{array}{l}.009 \\
(.009)\end{array}$ & $\begin{array}{l}.024 \\
(.009)\end{array}$ & $\begin{array}{l}-.001 \\
(.009)\end{array}$ & $\begin{array}{l}.032 \\
(.009)\end{array}$ \\
\hline 2,500-99,999 & $\begin{array}{c}-.012 \\
(.008)\end{array}$ & $\begin{array}{c}-.002 \\
(.008)\end{array}$ & $\begin{array}{c}-.003 \\
(.008)\end{array}$ & $\begin{array}{l}-.009 \\
(.007)\end{array}$ & $\begin{array}{c}-.011 \\
(.008)\end{array}$ \\
\hline Under 2,500 & $\begin{array}{l}.022 \\
(.009)\end{array}$ & $\begin{array}{l}-.007 \\
(.008)\end{array}$ & $\begin{array}{l}-.021 \\
(.008)\end{array}$ & $\begin{array}{l}.010 \\
(.008)\end{array}$ & $\begin{array}{l}-.021 \\
(.008)\end{array}$ \\
\hline Region & & $* * *$ & $* * *$ & $* * *$ & \\
\hline West & $\begin{array}{c}-.010 \\
(.011)\end{array}$ & $\begin{array}{c}.014 \\
(.011)\end{array}$ & $\begin{array}{c}-.003 \\
(.011)\end{array}$ & $\begin{array}{c}.006 \\
(.011)\end{array}$ & $\begin{array}{c}-.002 \\
(.011)\end{array}$ \\
\hline East & $\begin{array}{l}.011 \\
(.012)\end{array}$ & $\begin{array}{l}.010 \\
(.011)\end{array}$ & $\begin{array}{c}.032 \\
(.011)\end{array}$ & $\begin{array}{c}.029 \\
(.011)\end{array}$ & $\begin{array}{c}.022 \\
(.011)\end{array}$ \\
\hline Midwest & $\begin{array}{l}.006 \\
(.010)\end{array}$ & $\begin{array}{l}.019 \\
(.010)\end{array}$ & $\begin{array}{l}.025 \\
(.010)\end{array}$ & $\begin{array}{c}.008 \\
(.009)\end{array}$ & $\begin{array}{r}-.009 \\
(.009)\end{array}$ \\
\hline South & $\begin{array}{c}-.007 \\
(.010)\end{array}$ & $\begin{array}{c}-.043 \\
(.009)\end{array}$ & $\begin{array}{l}-.054 \\
(.009)\end{array}$ & $\begin{array}{c}-.043 \\
(.009)\end{array}$ & $\begin{array}{r}-.010 \\
(.009)\end{array}$ \\
\hline
\end{tabular}

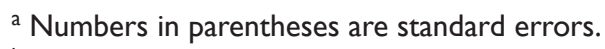

b $*$ Chi Square value $\leq .05$

$* *$ Chi Square value $\leq .01$

$* * *$ Chi Square value $\leq .001$ 
The idea that a household head is more likely to belong to voluntary associations is not borne out, except with respect to belonging to job-related associations. This may simply reflect that household heads are more likely to have a job than others or that having a job is somewhat of a prerequisite for being considered a head. At any rate, with the exception of jobrelated affiliations, this variable appears to have no independent consequence.

The two demographic variables, community size and region of residence, are significantly associated with participation, but the patterns are quite different. Both are associated with belonging to recreational associations, with people who live in large metropolitan areas and people who live in the East and Midwest being more likely to belong. Other than this, community size is associated with church-related and civic/political groups while region is associated with job-related and fraternal/ service organizations. Residents of nonmetropolitan areas are more likely to belong to church-related associations than are city dwellers, but they are less likely to be affiliated with civic/political organizations. Southerners are less likely to belong to job-related and fraternal/service associations than are residents of other regions.

In an additional analysis, the nine independent variables were examined for possible interaction effects on membership in each of the types of voluntary associations. Although the patterns of affiliation associated with community size and region of residence are quite different, these two independent variables are the only ones found to have a significant interaction effect on membership (data not shown). In the West, residents of large metropolitan areas are less likely to belong to church-related, job-related, and fraternal/service groups while residents of nonmetropolitan areas are the most likely to belong to these types of organizations. For all three types, the proportional difference is relatively large. The East and, especially, the South appear to be opposite the West in this respect with persons in the large metropolitan areas being more likely to belong to fraternal/service, job-related, and church-related groups. Community size does not appear to be a factor in determining social participation in the Midwest.

The differential pattern of affiliation by community size, region, and the interactions between them strongly indicate that studies based on limited areas such as a specific city or a geographic region may not be representative of patterns of affiliation in general and should not be interpreted this way.

The findings that only two of the nine independent variables examined here are significantly related to all five types of associations strongly suggests that joining is multidimensional. This conclusion gains further support from the fact that coefficients tend to be more than two standard errors from each other (see Table 1). However, it is possible to directly test whether the effects of these variables differ significantly by association type. Using the same linear probability technique outlined above, the probability of belonging to any organization was estimated from a model containing the nine independent variables, five dummy variables representing membership in each type of organization and the interaction terms derived by cross-multiplying them. Separate analyses were conducted for the interaction of organizational type and each independent variable. Results indicate at least one significant interaction term for all independent variables except race (Tables available from authors upon request). In other words, the effects of all variables except race differ for at least one type of organization. Even education, which has consistent positive effects on belonging does not operate in precisely the same way across organizational types. We would also note that 
the alpha reliability coefficient for the scale of number of types of organizational memberships is only .38, much too low to be considered acceptably reliable and another indication of multidimensionality.

\section{Conclusion}

In this study, nine independent variables previously identified in the literature as correlates of affiliation were examined in relation to five different types of associations. Each of these variables, controlling simultaneously for all of the others, was related to belonging to at least one type of association, but only two, race and education, were found to be significantly related to all five. Thus, it is inappropriate to consider the other variables as correlates of affiliation or determinants of membership in voluntary associations in general.

Theories about educational and racial effects have generally focused upon variable-specific explanations such as instrumental vs. social-emotional or ethnic-community vs. compensatory organizations. While explanations of this sort provide insight into the nature of the relationships between these characteristics and participation in voluntary organizations, theories also need to account for the more general impact of education and race on affiliation per se. In other words, our findings indicate that the better educated and Blacks are more likely than others in the respective categories of these variables to belong to all of the types of organizations included here, not just certain ones.

On the other hand, the lack of unidimensionality for the other seven independent variables presents a different, but equally important, interpretive problem. Explanations of why people belong to various voluntary associations typically have been derived from an analysis of the characteristics of members. And, when membership is measured simply as belonging to any one or more or a number of different kinds of groups or total number of memberships, the tendency has been to develop explanations focusing on psychological or cultural predispositions to join any organizations. In essence, the emphasis has been upon the characteristics of joiners versus nonjoiners. However, the findings presented in this study indicate that this kind of explanation can be quite misleading. For example, Curtis (1971) suggests that the under-involvement of American women in relation to American men, but their overinvolvement in relation to women from other countries, may reflect a form of deflected achievement. In other words, women participate in voluntary associations as a way of compensating for their exclusion from more rewarding activities. Our data show, however, that women are under-represented in some types of associations, but not in others. Thus, a more plausible explanation for gender differences in participation must take this variable's multidimensionality into account, e.g., gender differences in participation may stem from differences in opportunity to participate in certain types of groups, rather than psychological predispositions to join (cf. Booth, 1973). Certainly Houghland and Christenson's (1982) finding that there is only a very modest relationship between values and belonging may also be construed as evidence that opportunity structures are important mediating variables between sociodemographic variables and voluntary association membership. Specifying the type of organization that a given factor is associated with should help us to develop a better understanding of the reasons for affiliation. Treating memberships in different types of organizations as interchangeable appears to have led to inaccurate conclusions. 


\section{Note}

The findings presented in this paper are based on data collected through a study supported by the National Science Foundation (GS-36754X). Clyde Z. Nunn was the principal investigator and the co-investigators were Harry J. Crockett, Jr. and J. Allen Williams, Jr. The authors would like to thank Nicholas Babchuk, David R. Johnson, and Jon Van Til for their useful suggestions leading to the preparation of this paper. This note is part of a paper presented at the 1984 meeting of the American Sociological Association in San Antonio, Texas.

\section{References}

Allardt, Erik, Pentti Jartti, Faina Jyrkila, Yrjooe Littuner

1958 "On the Cumulative Nature of Leisure Activities," Acta Sociologica 3: 165-172.

Babchuk, Nicholas and Alan Booth

1969 "Voluntary Association Membership: A Longitudinal Analysis," American Sociological Review 34 (February): 31-45.

Babchuk, Nicholas, George Peters, Danny Hoyt, and Marvin Kaiser

1979 "The Voluntary Associations of the Aged," Journal of Gerontology 34 (July): 579-87.

Booth, Alan

1973 "Sex and Social Participation," American Sociological Review 37 (April): 183-92.

Booth, Alan, Nicholas Babchuk, and Alan Knox

1968 "Social Stratification and Membership in Instrumental-Expressive Voluntary Associations," Sociological Quarterly 9 (Autumn): 427-39.

Curtis, James

1971 "Voluntary Association Joining: A Cross-National Comparative Note," American Sociological Review 36 (October): 872-80.

Cutler, Stephen

1977 "Aging and Voluntary Association Participation," Journal of Gerontology 32 (July): 340-79.

Edwards, John and Randall White

1980 "Predictors of Social Participation: Apparent or Real," Journal of Voluntary Action Research 9 (1): 60-73.

Grizzle, J., C. Starmer, and G. Koch

1969 “Analysis of Categorical Data b Linear Models,” Biometrics 25 (September): 489-504.

Guterbock, Thomas and Bruce London

1983 "Race, Political Orientation, and Participation," American Sociological Review 48 (August): 439-53.

Houghland, James

1979 "Toward a Participation-based Typology of Voluntary Organizations," Journal of Voluntary Action Research 8: 84-92.

Houghland, James, and James Christenson

1982 "Voluntary Organizations and Dominant American Values," Journal of Voluntary Action Research 11: 7-26. 
Hyman, Herbert and Charles Wright

1971 "Trends in Voluntary Association Memberships of American Adults: Replication Based on Secondary Analysis of National Sample Surveys," American Sociological Review 36 (April): 191-206.

Jacoby, Arthur

1966 "Personal Influence and Primary Relationships: Their Effect on Associational Membership.” Sociological Quarterly 7 (Winter): 76-84.

Klobus-Edwards, Patricia, John Edwards, and D. Klemmack

1978 "Differences in Social Participation: Blacks and Whites." Social Forces 56 (June): 1035-52.

Klobus-Edwards, Patricia, John Edwards, and Ann Watts

1984 "Women, Work and Social Participation," Journal of Voluntary Action Research 13 (January-March) : 7-22.

Knoke, David and R. Thomsen

1977 "Voluntary Association Membership Trends and the Family Life Cycle." Social Forces 56 (September): 48-65.

Lemon, Mona, B. Palisi, and P. Jacobson

1972 "Dominant Statuses and Involvement in Formal Voluntary Associations." Jour-

McPherson, J. Miller nal of Voluntary Action Research 1 (Spring): 30-42.

1981 “A Dynamic Model of Voluntary Affiliation,” Social Forces 59 (March):705-28.

Nunn, Clyde Z., Harry J. Crockett, Jr., and J. Allen Williams, Jr.

1978 Tolerance for Nonconformity (San Francisco: Jossey-Bass).

O’Donnell, L.

1983 “The Social World of Parents,” Marriage and Family Review 5: 9-36.

Schmidt, Alvin J.

$1980 \quad$ Fraternal Organizations (Westport, Conn.: Greenwood Press).

Sills, David 1957

The Volunteers (New York: Free Press).

Smith, D. H.

1975 "Voluntary Action and Voluntary Groups." Pp. 247-270 in Alex Inkeles, James

Coleman, and Neil Smelser (eds.), Annual Review of Sociology. Palo Alto, Cal.: Annual Reviews Incorporated.

Swafford, Michael

1980 "Parametric Techniques for Contingency Table Analysis," American Sociological Review 45 (August): 664-90.

Tomeh, Aida

1973 "Formal Voluntary Organizations: Participation, Correlates, and Interrelationships," Sociological Inquiry 43 (3-4): 89-122.

Williams, J. Allen, Jr. and Louis St. Peter

1977 "Ethnicity and Socioeconomic Status as Determinants of Social Participation: A Test of the Interaction Hypothesis.” Social Science Quarterly 57 (March): 892-98. 